\title{
The Bélinga Iron Ore Deposit ( 2.8 Ga), NE-Gabon: Reactualization and New Interpretations on Crests
}

\author{
Stévy Retonda Kondja \\ Simplice Marin Ndong Ondo \\ Ambroise Edou Minko \\ University of Sciences and Technologies of Masuku, URESTE, Geology \\ Department, Franceville, Gabon \\ Francis Mayaga Mikolo \\ General Direction of Geology and Research Mines, Libreville, Gabon \\ doi: 10.19044/esj.2017.v13n24p307 URL:http://dx.doi.org/10.19044/esj.2017.v13n24p307
}

\begin{abstract}
The Bélinga iron ore deposit is the biggest iron ore situated in NEGabon. Very little is known about that iron ore and available data are sometimes incompatible. We revisited documents that evoke the deposit to reactualize and propose new interpretations. The Bélinga iron ore deposit is composed of thirteen (13) N-S mineralized crests that underwent 3 tectonic events, folding $\left(D_{1}\right)$, fracture $\left(D_{2}\right)$ and folding $\left(D_{3}\right)$. The ore is subdivided into four main categories which are blue and yellow ores, hematitic phyllites and enriched itabirites, with variable amounts of canga. The estimated reserves at Bélinga are $\sim 384 \mathrm{Mt}$ of high grade ore $(\mathrm{Fe}>60 \%$ and $\mathrm{P}<$ $0.09 \%$ ), and more than $1 \mathrm{Gt}$ by considering an iron ore with $\mathrm{Fe}>50 \%$ and $\mathrm{P}$ $<0.18 \%$.
\end{abstract}

Keywords: Mesoarchaean, Bélinga Group, BIFs, iron ore, Gabon

\section{Introduction}

Archaean and Paleoproterozoic represent a long period of Precambrian times that recorded the deposition of Iron Formations widespread in most of Archean cratons with maximum abundance around $2.5 \mathrm{Ga}$ (Bontognali et al., 2013; Pecoits et al., 2009; Klein, 2005). Most of iron ores of this period are originated from enormous altered Banded Iron Formations (BIFs) hosted in greenstone belts and constitute the essential resources of iron like those in the Hamersley province in Australia (Dalstra, 2014; Webb et al., 2003), Quadrilátero Ferríferro and Carajás in Brazil (Fabre et al., 2011; Spier et al., 2003), Ashan region in North of China (Wang et al., 2014a), Orissa region in 
Eastern India (Roy \& Venkatesh, 2009) and Transvaal basin in South Africa (Schweigart, 1965).

NE-Gabon, NW-Congo and S-Cameroon contain greenstone belts hosting BIFs. In Gabon, the greenstone belt hosting BIFs is called Bélinga Group (Combes et al., 1986a). It's suggested that the supergene alteration of these BIFs resulted in the formation of the Bélinga iron ore deposit made of about ten crests in NE-Gabon (Martini \& Makanga, 2002; Combes et al., 1986a; Sims, 1973). Parameters like Fe contents and tonnage were estimated (Combes et al., 1986a; Sims, 1973; Plegat, 1955b; Chochine, 1950, 1951, 1952). However, recent documents (e.g. Martini \& Makanga, 2002) present some differences when compared to those older (e.g. Combes et al., 1986a), from where the necessity of revisiting the iron ore.

This paper (i) presents old data on the Bélinga iron ore deposit, (ii) examines recent data and (iii) updates, after comparison, data and propose new precisions.

\section{Regional geological setting}

The Bélinga iron ore deposit is situated in the Ogooué-Ivindo province, NE-Gabon. The region is a granites-greenstones terrain composed of an 3.0-2.7 Ga Archaean basement and a $\sim 2.8 \mathrm{Ga}$ greenstone belt called Bélinga Group (Thiéblemont et al., 2009b; Chevallier et al., 2002; Prian et al., 1998; Prian \& Johan, 1989) (Fig. 1). The basement includes granites, gneisses and migmatites that underwent principally granulite facies metamorphism. The Bélinga Group consists of meta-ultrabasites, amphibolepyroxene rocks, amphibolites, amphibole gneisses, metasediments and BIFs essentially metamorphized under amphibolite facies, and locally granulite facies (Thiéblemont et al., 2009b; Chevallier et al., 2002). Quaternary sediments in the border with Congo are noted.

With a $\mathrm{N} 130^{\circ}$ of general trend (Chevallier et al., 2002; Stahl \& Pohner, 1957), the Bélinga Group is crosscut by two principal fault families, one is $\mathrm{N} 120^{\circ}$ and the other is $\mathrm{N} 40^{\circ}$ (Combes et al., 1986a). The Nkol shear zone, an important sub-vertical fracture with a right lateral trend and oriented $\mathrm{W}-\mathrm{E}$ to WNW-ESE (Bassot, 1988), crosscuts the NE-Gabon region in two parts. The Bélinga iron ore deposit is located at $\sim 55 \mathrm{~km}$ in North of the Nkol shear zone (Fig. 1).

\section{Methodology}

This work is based on the synthesis and the interpretation on the one hand of old data before 2000 (Stahl \& Pohner, 1957; Anonymous, 1957; Telfair \& Hole, 1960; Sims, 1973; Combes et al., 1986a; Combes, 1986c), and on the other hand on the synthesis and the interpretation of data after 2000 (Martini \& Makanga, 2002; Thiéblemont et al., 2009a; Thiéblemont, 
2009c) especially on cartography, tectonics, petrography and mineralogy, and finally on the geochemistry and tonnage of the Bélinga iron ore deposit.

New precisions are made by crossing old and recent data to highlight differences observed with authors in cartography, tectonics, petrography and mineralogy, geochemistry and tonnage.

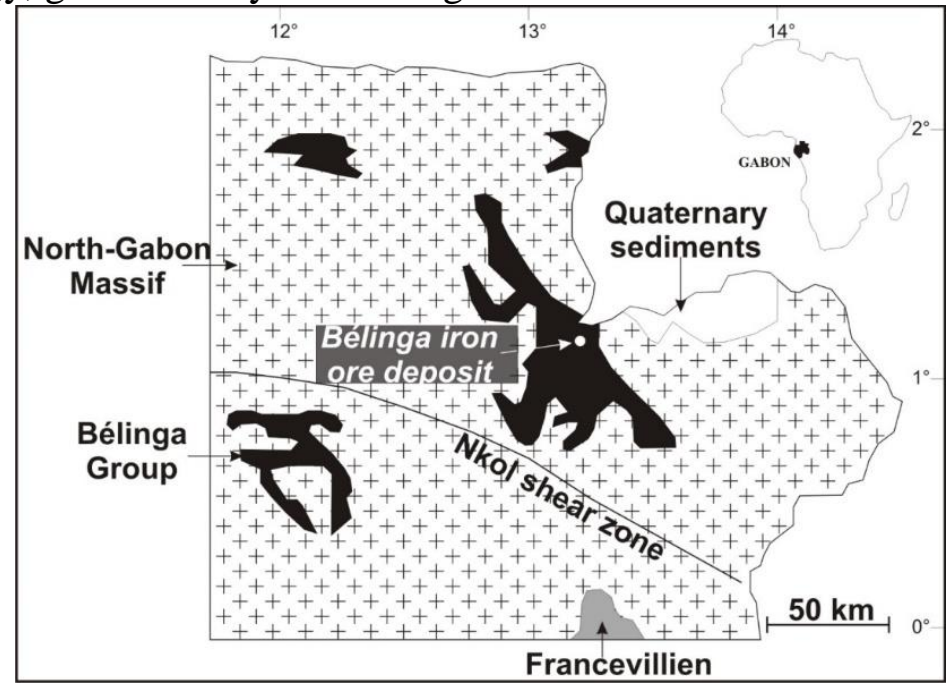

Figure 1: Simplified geological map of NE-Gabon (modified after Chevallier et al., 2002).

\section{Results}

Results before 2000

\section{Cartography}

The cartography of the Bélinga iron ore deposit improved with years (Fig. 2). Anonymous (1957) adopts a representation of the deposit in which many outcrops of the ore and itabirites are recognized within nine (9) main crests (Fig. 2a). These crests, commonly named with alphabetic letters are North- and South-Babiel, AD, L, the great South crest, AK, AC, AM-AH and Cocotiédié. Sims (1973) mentioned that the deposit is $30 \mathrm{~km}$ long and $\sim 8$ $\mathrm{km}$ large. According to this author, it is made of nine crests which are Momba, Bakouélé, Babiel, Kombi, Okumé, Cocohédié, North-Bakota, South-Bakota and South South-Bakota (Fig. 2b). Combes et al. (1986a) propose a cartographic representation with thirteen (13) crests including East- and West-Mvadhi, Mombo, Bakouélé, Babiel, Kombo, Okumé, Cocotiédié, North-Bakota, Middle-Bakota, South-Bakota, South SouthBakota and Bamba (Fig. 2c).

\section{Tectonic}

Three main chronologically tectonic events $\mathrm{D}_{1}, \mathrm{D}_{2}$ and $\mathrm{D}_{3}$ affect the ore (Sims, 1973; Combes et al., 1986a). $\mathrm{D}_{1}$ event, resulting from metamorphic deformation associated with mineralogical recrystallization, is marked by isoclinal folds responsible of great structures observed at Bélinga. 
$\mathrm{D}_{1}$ folds are subdivided in an area of monoclinal $\mathrm{W}$ or $\mathrm{E}$ dip folds and an area of tight folds. $\mathrm{D}_{2}$ event is marked by fractures following two principal directions, $\mathrm{N} 120^{\circ}$ and $\mathrm{N} 40^{\circ}$. The $\mathrm{N} 120^{\circ}$ faults family has a right lateral trend and the $\mathrm{N} 40^{\circ}$ faults family has a vertical trend (Combes et al., 1986a). $\mathrm{D}_{3}$ event is characterized by decimeter folded structures of kink bands-type, with straight limbs and inclined axial planes affecting only platy ore and would be contemporaneous to the enrichment phase (Combes et al., 1986a; Sims, 1973). In general, itabirites and resulting mineralized rocks are frequently high folded and present dips varying from 5 to $85^{\circ}$, either in $\mathrm{E}$ or $\mathrm{SE}$, or in $\mathrm{W}$ or NW. On Babiel crest for example, the platy ore is $\mathrm{W}$ oriented and $55^{\circ}$ dip.

\section{Petrography and mineralization}

At Bélinga, we have unmineralized and mineralized terrains. Unmineralized terrains are found in surface and in footwall of crests, sometimes as intrusion (Fig. 3). Those terrains include soils, mudrocks, schists, micaschists, amphibolites and metavolcanic rocks (Combes et al., 1986a). At the top and on the slopes of crests, mineralized terrains are canga and scree deposits, and more deeper we have itabirites s.s and argillaceous itabirites. The essential of the iron ore is irregularly concentrated between canga (and scree deposits) and itabirites (Fig. 3).

The ore is essentially composed of platy hematite with variable amounts of magnetite and goethite. Terminology used to classify iron ore is based upon color, hardness and structure (Tab. 1).

Scree deposits consist of decimeter components and stability is assured by an argillaceous limonitic cement.

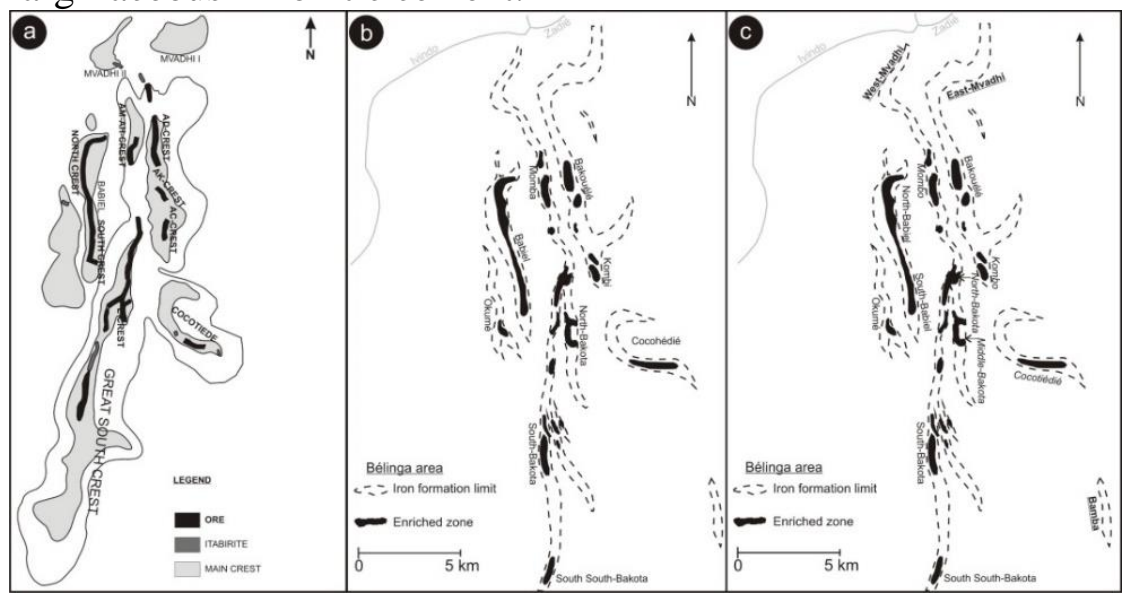

Figure 2: Evolution in the cartography of the Bélinga area with prospected crests. (a), (b) and (c) are modified maps respectively after Anonymous (1957), Sims (1973) and Combes et al. (1986a). For (c), names in bold type and underlined are crests prospected after 1980; names in italic show crests presenting differences between Sims (1973) and Combes et al. 
Canga is more abundant than scree deposits. It's enriched in iron ( $\mathrm{Fe}>$ $55 \%$ ) and presents components varying from centimeter (pisolitic canga) to meter, with a matrix essentially composed of iron hydroxides (Anonymous, 1957; Combes et al., 1986a).

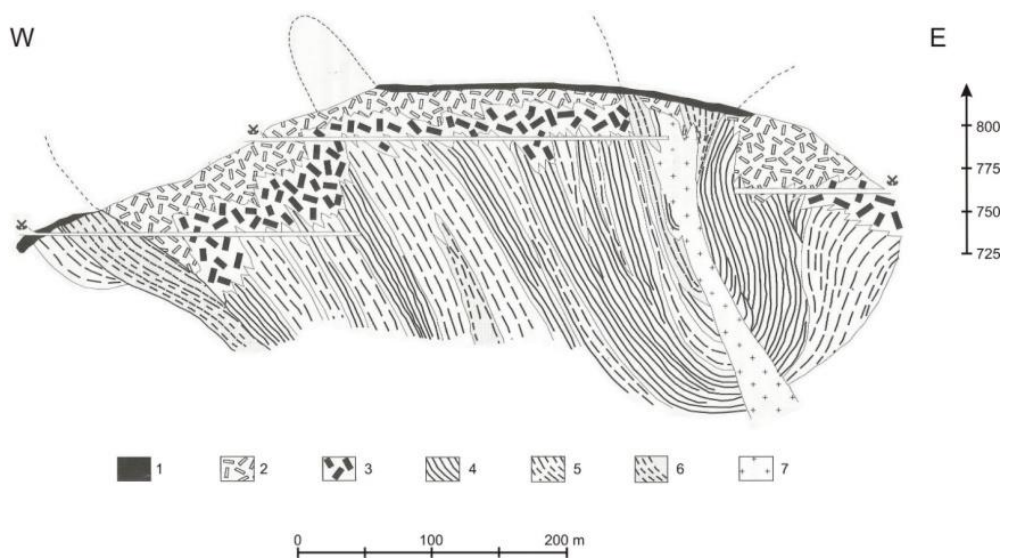

Figure 3: Interpretative cross section of South-Bakota crest (Sims, 1973). 1-Canga and soils; 2-Hydreous and indurated platy ore; 3 -Soft platy hematitic ore; 4-

Siliceous/argillaceous itabirites; 5-Hematitic phyllites; 6-Clays; 7-Intrusion.

Table 1: Criteria used to classify iron ore at Bélinga (Socomine, 1977 in Combes et al., 1986a).

\begin{tabular}{|c|c|}
\hline Color & Y= yellow \\
& $\mathrm{B}=$ blue \\
\hline \multirow{2}{*}{ Hardness } & $\mathrm{S}=$ soft \\
& $\mathrm{M}=$ medium-hard \\
$\mathrm{D}=$ hard
\end{tabular}

Deeper in the ore (> 5m), Fe content is generally higher than $50 \%$. The ore is subdivided into four (4) main categories: hematitic phyllites, yellow ore, blue ore and enriched itabirite (Martini \& Makanga, 2002; Combes et al., 1986a). Hematitic phyllites are brown to dark colored, or even reddish depending on hematite enrichment. They are composed of disseminated quartz grains with thin layers of mud and hematite. Fe contents can reach up $60 \%$. They are directly originated from argillaceous itabirites by weathering, followed by Fe-enrichment. Yellow ore mainly consists of indurated platy hematite in which it is not rare to observe vacuoles and argillaceous levels filled of iron hydroxides. The ore has Fe contents > 60\% and is mainly subdivided into soft, medium-hard and hard platy ore (Tab. 2). The blue ore owes its name due to metallic light blue to dark blue colors of the hematite 
which is its principal mineral. It has Fe contents $>60 \%$ and is also subdivided into soft, medium-hard and hard platy ore. Blue and yellow ores present a granular ore type called " jacuntinga " (Tab. 2) with Fe contents around $60 \%$. Enriched itabirites represent a transitional term between the iron ore $(\mathrm{Fe} \geq 55 \%)$ and itabirites $(\mathrm{Fe}<40 \%)$ (Combes et al., 1986a). Its average content of iron is $\sim 50 \%$, but it can reach $60 \%$. Generally, mediumhard and hard platy hematite ore types are most represented, the last making $79.5 \%$ of the total volume of the ore (Sims, 1973).

Ferriferous rocks are composed of itabirites $s . s$ and argillaceous itabirites.

Table 2: Principal petrographic types (mineralized rock) found in the area of the Bélinga iron ore deposit (Socomine, 1977 and Sims 1978 in Combes et al., 1986a). Abbreviation used for the ore and primary ferruginous rocks are based on criteria in Table 2. Scree deposits, clay, schist, micaschist, amphibolite, métavolcanics and others magmatic rocks are not included in this classification.

\begin{tabular}{|c|c|c|}
\hline \multirow{4}{*}{ Ore } & YSGP or BSGO & Jacutinga \\
\cline { 2 - 3 } & YSPO or BSPO & Soft platy ore \\
\cline { 2 - 3 } & YMPO or BMPO & Medium-hard platy ore \\
\cline { 2 - 3 } & YDPO or BDPO & Hard massive ore \\
\cline { 2 - 3 } & HP & Hematitic phyllite \\
\cline { 2 - 3 } & ITE & Enriched itabirite \\
\cline { 2 - 3 } & CG & Canga \\
\hline \multirow{4}{*}{ Primary ferruginous rocks } & IT & Itabirite \\
\cline { 2 - 3 } & ITA & Argillaceous itabirite \\
\hline
\end{tabular}

\section{Geochemistry and tonnage}

The Bélinga iron ore deposit is the biggest iron deposit in Gabon with more than $600 \mathrm{Mt}$ of high grade ore ( $\mathrm{Fe}>60 \%)$, but only $384 \mathrm{Mt}$ are less phosphorous (Combes et al., 1986a; Telfair \& Hole, 1960), the more important reserves being on Babiel crest (Tab. 3).

Few chemical elements have been analyzed in relation with the ore. The analyses focus on iron, silica, alumina and phosphor (Tab. 3-4).

Table 3: Contents and tonnage of prospected crests of the Bélinga iron ore deposit. In brackets, numbers 1 and 2 refer to Combes et al. (1986a), and Socomine (1983) in Combes (1986c) respectively; letters $a$ and $b$ represent determined and inferred reserves respectively.

Mineralized height is $\geq 5 \mathrm{~m}$.

\begin{tabular}{|c|c|c|c|c|c|c|c|}
\hline Ore & \multirow[t]{2}{*}{ Crests } & \multicolumn{5}{|c|}{ Content (\%) } & \multirow[t]{2}{*}{ Tons (Mt) } \\
\hline $5 \frac{\sqrt{0}}{0}$ & & $\mathrm{SiO}_{2}$ & $\mathrm{Fe}_{2} \mathrm{O}_{3}$ & $\mathrm{Al}_{2} \mathrm{O}_{3}$ & $\mathrm{P}_{2} \mathrm{O}_{5}$ & OI & \\
\hline$\overline{0}$ & $\operatorname{Mombo}(1, a)$ & 3.66 & 62.9 & 3.52 & 0.055 & .41 & 52.597 \\
\hline in & $\operatorname{Kombo}(1, a)$ & 3.58 & 62.6 & 2.72 & 0.073 & .78 & 23.012 \\
\hline $\begin{array}{l}\hat{\Theta} \\
\hat{U}\end{array}$ & North-Babiel $(1, a)$ & 3.28 & 65.09 & 1.52 & 0.071 & .71 & 110.685 \\
\hline
\end{tabular}




\begin{tabular}{|c|c|c|c|c|c|c|c|}
\hline South-Babiel (1,a) & 3.79 & 62.85 & 3.22 & 0.064 & .76 & 53.769 \\
\cline { 2 - 7 } & Okumé (2,b) & 2.84 & 62.77 & 2.9 & 0.072 & .73 & 8.4 \\
\hline Cocotiédié & & & & & & 4.7 \\
\cline { 2 - 8 } & North-Bakota (1,a) & 2.01 & 65.29 & 2.61 & 0.054 & .93 & 14.902 \\
\cline { 2 - 8 } & Middle-Bakota (2,a) & 1.69 & 60.98 & 6.69 & 0.047 & .68 & 17.4 \\
\hline South-Bokata (1,a) & 3.31 & 64.18 & 2.9 & 0.054 & .8 & 90.208 \\
\hline S. South-Bakota (2,a) & 2.4 & 58 & 5.76 & 0.082 & .64 & 8.2 \\
\hline Total & & & & & & 383.873 \\
\hline
\end{tabular}

Table 4: Average chemical composition and varying thickness of different types of iron ore at Bélinga. Itabirite s.s is added to see differences in Fe and Si contents with ores. Values are based on some historical data from South South-Bakota, Middle-Bakota and Okumé crests (Combes et al., 1986b).

\begin{tabular}{|c|c|c|c|c|c|c|}
\hline & $\mathrm{Fe}_{2} \mathrm{O}_{3} \mathrm{t}(\%)$ & $\mathrm{SiO}_{2}(\%)$ & $\mathrm{Al}_{2} \mathrm{O}_{3}(\%)$ & $\mathrm{P}(\%)$ & LOI (\%) & Thickness (m) \\
\hline Canga & 56.73 & 2.36 & 7.206 & 0.169 & 7.68 & $1-10$ \\
\hline Hematitic phyllites & 54.63 & 6.61 & 6.63 & 0.116 & 7.54 & $3-32.5$ \\
\hline Yellow ore & 61.27 & 1.77 & 4.63 & 0.118 & 4.97 & $3-47.5$ \\
\hline Blue ore & 64.50 & 1.63 & 2.40 & 0.097 & 2.82 & $1-32$ \\
\hline Enriched itabirite & 51.69 & 17.36 & 3.21 & 0.133 & 4.48 & $7-46$ \\
\hline Itabirite $s . s$ & 34.26 & 47 & 0.98 & 0.076 & 2.46 & $6-20$ \\
\hline
\end{tabular}

\section{Results after 2000}

\section{Cartography}

Martini \& Makanga (2002) propose a map gathering the cartographic data of Sims (1973) and Combes et al. (1986a). Thiéblemont (2009c) locates the Bélinga iron ore deposit from a Gabonese geological map. These cartographic representations of the iron deposit are more or less identical to the old representations. The new synthesis and the interpretation based on the reactualized geological map of Gabon and old data enable us to propose a map with thirteen crests on a geological bottom made of itabirites, greenstones and basement (Fig. 4). 


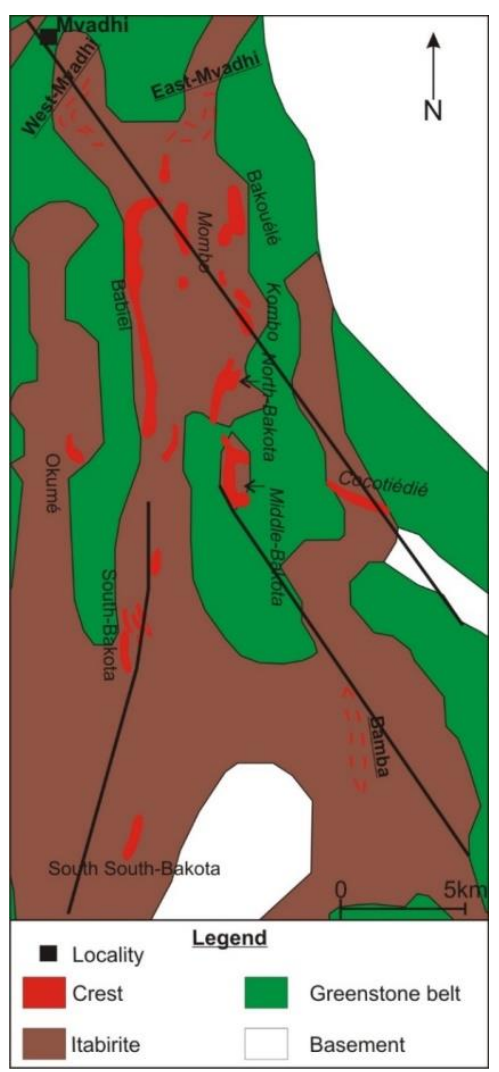

Figure 4: Reactualized map of the Bélinga iron ore deposit. The geological background map is from Thiéblemont $(2009 \mathrm{c})$.

Tectonic, petrography, mineralogy, geochemistry and tonnage

Recent results on petrographic interpretations, mineralization, geochemistry and tonnage remain identical to old data.

About tectonics, figures 5 and 6 respectively show cross sections realized on Okumé and Middle-Bakota crests. From top to bottom we have canga and/or scree deposits, a mixing of yellow/blue ores and finally enriches itabirites, in which it's not rare to find argillaceous intercalations. These cross sections show the role played by tectonics via local to regional reverse faults and the multiple associated deformations. On the Okumé cross section (Fig. 5), the ore (yellow and blue) is close to the surface and quickly reached because the canga is not very thick. From side to side of the reverse faults, the ore is frequently thicker and deeper in the lowered compartments in contrary to the raised compartments (pit 6-15w, 6-05w, 6-17). On MiddleBakota, as well as on Okumé crest, we also notice that the ore thickens when we move away from the top of the crest towards its sides (Fig. 5-6). The different levels of the ore are strongly inclined. The weathering level is irregular and affected by micro-folds. 


\section{Discussion}

Anonymous (1957) proposes a cartographic representation of the Bélinga iron ore deposit based on the sections traversed by the geologists Park, Hole, Michel in 1956 who mentioned the zones where the ore and itabirites (BIFs) were recognized. Nine (9) mineralized crests of several hundreds of square meters were named (Fig. 2a). Sims (1973) proposes a map of the deposit with 9 mineralized crests with some differences with the old map (Fig. 2b) and Combes et al. (1986a) propose a new cartographic representation with 13 crests (Fig. 2c). The comparison of these cartographic data emphasizes differences on the number and the name of crests of the iron ore deposit. The current synthesis and the interpretations carried out during this work show 13 crests and agree to the results of Combes et al. (1986a).

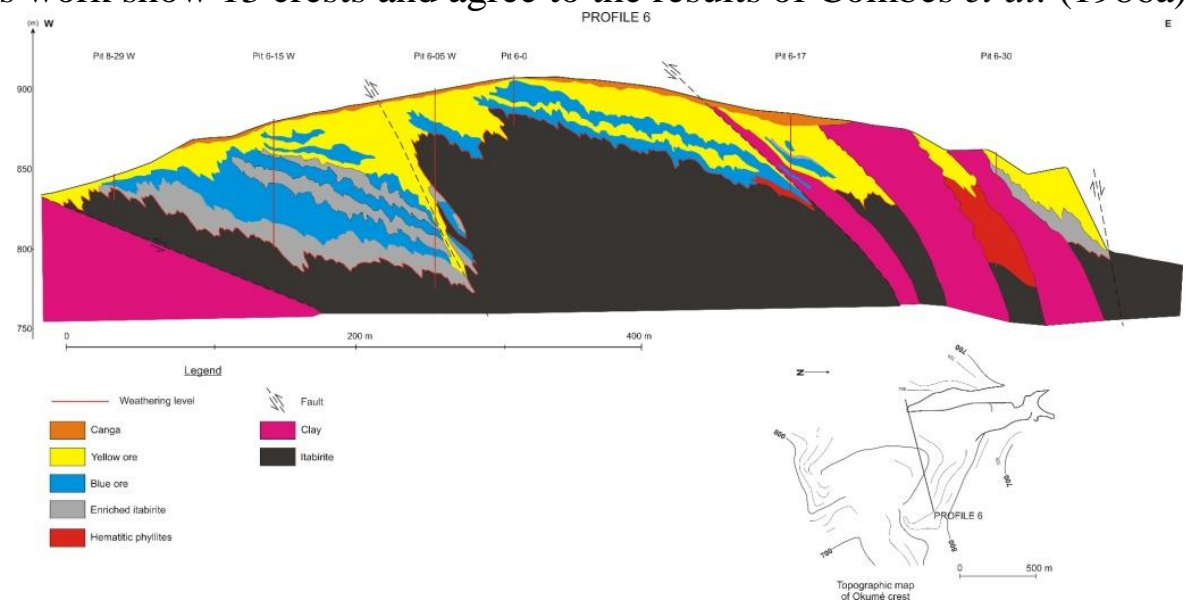

Figure 5: Cross section of profile 6 from Okumé crest (modified after Combes et al., 1986b). Blue and yellow ores are globally taken without considering hardness and structure. Itabirite refers to itabirite s.s and argillaceous itabirite. Vertical red lines represent realized

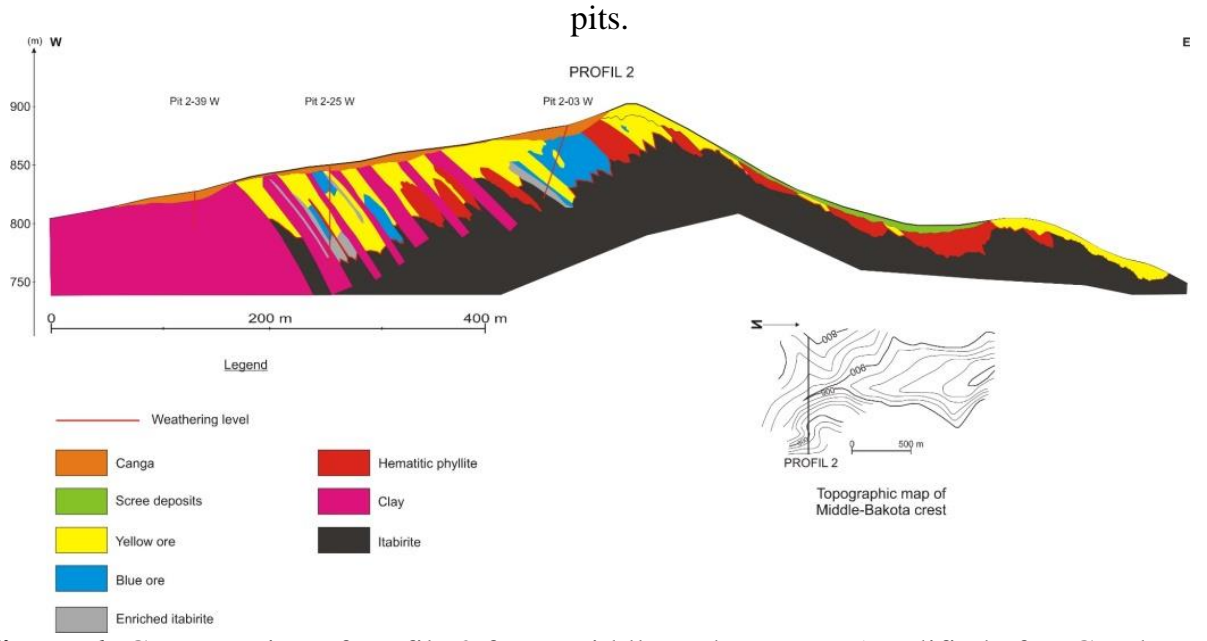

Figure 6: Cross section of profile 2 from Middle-Bakota crest (modified after Combes et al., 1986b). 
About the names of crests, Anonymous (1957) and Sims (1973) mention 9 mineralized crests whereas Combes et al. (1986a) find 13. The current synthesis confirms the results of Combes et al. (1986a) by harmonizing names. On Bakota crests, the old maps (Anonymous, 1957) taken again by Combes et al. (1986a) indicate Middle-Bakota and NorthBakota contrary to Sims (1973) who indicates only North-Bakota (Fig. 2). For Cocotiédié, Kombo and Mombo, we regard them as true names (Combes et al., 1986a), in opposition to misspellings on the names suggested by Sims (1973). Martini \& Makanga (2002) and Thiéblemont et al. (2009a) did not take into account all the data of Combes et al. (1986a) when writing recent documents.

A summary table (Tab. 5) specifies the harmonization of all these data. A new map of the deposit based on the known positions of crests coupled to a recent geological map is also proposed (Fig. 4).

Table 5: Summary of proposed names (Anonymous, 1957; Sims, 1973; Combes et al., 1986a) and new proposed names of mineralized prospected crests from the Bélinga iron ore deposit.

\begin{tabular}{|c|c|c|c|}
\hline \multicolumn{5}{|c|}{ Names of crests of the Bélinga iron ore deposit } \\
\hline Anonymous (1957) & Sims (1973) & Combes et al. (1986a) & Present paper \\
\hline Babiel Nord & \multirow{2}{*}{ Babiel } & Babiel & \multirow{2}{*}{ Babiel } \\
\hline Babiel Sud & Bakouélé & Bakouélé & Bakouélé \\
\hline AD & & Bamba & Bamba \\
\hline \multirow{2}{*}{ L } & North-Bakota & North-Bakota & North-Bakota \\
\cline { 2 - 4 } & & Middle-Bakota & Middle-Bakota \\
\hline \multirow{2}{*}{ Great South crest } & South-Bakota & South-Bakota & South-Bakota \\
\cline { 2 - 4 } & South South-Bakota & South South-Bakota & South South-Bakota \\
\hline Cocotiédé & Cocohédié & Cocotiédié & Cocotiédié \\
\hline AK & \multirow{2}{*}{ Kombi } & Kombo & Kombo \\
\hline AC & Momba & Mombo & Mombo \\
\hline AM-AH & & East-Mvadhi & East-Mvadi \\
\hline & & West-Mvadhi & West-Mvadi \\
\hline & Okumé & Okumé & Okumé \\
\hline
\end{tabular}

Petrographic interpretations, mineralization, geochemistry and tonnage remain identical to the old data. The Bélinga iron ore deposit is composed of yellow and blue ores, accompanied by variable quantities of hematitic phyllites and enriched itabirites, of which the thicknesses are very variable (Thiéblemont et al., 2009a; Martini \& Makanga, 2002; Combes et al., 1986a; Combes, 1986c; Sims, 1973; Anonymous, 1957).

On a tectonic point of view, new interpretations highlight the various deformation phases $D_{1}, D_{2}$ and $D_{3}$, recognized by Sims (1973) and Combes 
et al. (1986a) which affected the deposit. The repetition and the strong dips of the mineralized zones (Fig. 3, 5-6) towards $\mathrm{E}$ or $\mathrm{W}$ on the one hand, and on the other hand as isoclinal folds characterize the $\mathrm{D}_{1}$ deformation phase. Local to regional reverse accidents characterize the $\mathrm{D}_{2}$ event, marked by fracturing according to the main directions $\mathrm{N} 40^{\circ}$ and $\mathrm{N} 120^{\circ}$. The weathering level, affected by decimeter micro-folds of kink bands-type characterize $\mathrm{D}_{3}$ event. The precise ages of these tectono-metamorphic events are not clearly known, but Thiéblemont et al. (2009a) suggest that they would be related to Neoarchaean orogen.

New interpretations show the role played by reserve faults within ore. On the realized cross section in figure 5, the thickness variation of ironbearing zone on both sides of the accidents suggests a creation of differential space consecutive to the faults and that the later should be contemporaneous to the supergene enrichment processes. They thus could not simply be limited to $\mathrm{D}_{2}$ event, but should have also played during $\mathrm{D}_{3}$ event. It's the first time that the interactions between tectonics and the iron-bearing zones on a short wavelength scale are proposed at Bélinga, particularly on Okumé crest.

The Bélinga iron ore deposit remains unexploited and the reserves are estimated at $\sim 384 \mathrm{Mt}$ of high grade ore ( $\mathrm{Fe}>55 \%$ and $\mathrm{P} \leq 0.1 \%$ ). If we consider an ore with $\mathrm{Fe}>50 \%$ and $\mathrm{P} \leq 0.15 \%$, the reserves exceed $1 \mathrm{Gt}$ (Martini \& Makanga, 2002). It's therefore an importance deposit, in comparison with other iron deposits (Tab. 6).

Table 6: Summary of some known iron ore deposits around the world in comparison to Bélinga. We expressly represent Bélinga with $\mathrm{Fe}>50 \%$ and not with $\mathrm{Fe}>60 \%$ to show $\mathrm{Fe}$ potentiality in Gabon.

\begin{tabular}{|c|c|c|c|c|c|}
\hline Iron ore & Country/Region & $\begin{array}{c}\text { Fe content } \\
(\%)\end{array}$ & $\begin{array}{c}\mathrm{P} \text { content } \\
(\%)\end{array}$ & $\begin{array}{r}\text { Tons } \\
(\mathrm{Mt})\end{array}$ & Authors \\
\hline Xi'Anshan & China & 34.22 & & 172.861 & Han et al. (2014) \\
\hline Bélinga & Gabon & $>50$ & $0.05-0.18$ & $>1.000$ & $\begin{array}{c}\text { Martini and } \\
\text { Makanga (2002); } \\
\text { Sims (1973) }\end{array}$ \\
\hline Nkout & Cameroon & $>50$ & & 72.5 & $\begin{array}{l}\text { Anderson } \text { et al. } \\
\text { (2014) }\end{array}$ \\
\hline Gongchanling & China & $>50$ & $<0.1$ & 150 & $\begin{array}{l}\text { Wang et al. } \\
(2014 \mathrm{~b}) \text {; Li et } \\
\text { al. (2014) }\end{array}$ \\
\hline Madoonga & Western Australia & 57.7 & & 68 & $\begin{array}{c}\text { Duuring et } \\
\text { Hagemann } \\
(2013)\end{array}$ \\
\hline Koolyanobbing & Western Australia & $>58$ & $<0.1$ & $>100$ & $\begin{array}{c}\text { Angerer et } \\
\text { Hagemann } \\
(2010)\end{array}$ \\
\hline Pico & Brazil & 67 & 0.05 & 313 & Spier et al. (2003) \\
\hline Águas Claras & Brazil & 68.23 & 0.17 & 376 & Spier et al. (2003) \\
\hline
\end{tabular}




\section{Conclusion}

The comparison of old data and recent investigations on the Bélinga iron ore deposit, in relation to the cartography, tectonics, petrography, mineralization, tonnage and geochemistry made on it allow us to propose new tectono-sedimentary precisions. The reactualized interpretation of the cartography highlights thirteen mineralized crests. The mineralization essentially consists of yellow and blue ores in platy hematite form, with hematitic phyllites and enriched itabirites. Tectonics confirms several episodes of deformation characterized by isoclinal folds, fracturing and micro-folds of the weathering level. The thickness variations of the ironbearing zone from side to side of tectonic accidents limiting kilometric blocks suggest the interactions between tectonics and the iron-bearing zones.

The Bélinga iron ore deposit is little known by public and scientific communities because of the insignificant number of scientific publications, of which last dates of about forty years. It still remains unexploited to date and the reserves of $\sim 384 \mathrm{Mt}$ of high grade ore makes this deposit one of the largest in Central Africa.

\section{Acknowledgements}

We thank the Geology Department of the Faculty of Sciences from the University of Sciences and Technologies of Masuku (USTM, Gabon) for supporting this study. We are also grateful for the General Direction of Geology and Research Mines (D.G.G.R.M) of Gabon and their staff to enable the use of their data.

\section{References:}

1. Anderson, K.F.E., Wall F., Rollinson G.K., \& Moon C.J. (2014). Quantitative mineralogical and chemical assessment of the Nkout iron ore deposit, Southern Cameroon. Ore Geology Reviews, 62, 2539.

2. Angerer, T., \& Hagemann, S.G. (2010). The BIF-Hosted High-Grade Iron Ore Deposits in the Archean Koolyanobbing Greenstone Belt, Western Australia: Structural Control on Synorogenic- and Weathering-Related Magnetite-, Hematite-, and Goethite-rich Iron Ore. Economic Geology, 105, 917-945.

3. Anonymous (1957). Les gisements de fer de la région de Mékambo. Rapport BRGM, F-2-225a, 17p.

4. Bassot, J.P. (1988). Apport de la télédétection à la compréhension de la géologie du Gabon. Chronique de la Recherche Minière, 491, 2534.

5. Bontognali, T.R.R., Fischer, W.W., \& Föllmi, K.B. (2013). Siliciclastic associated banded iron formation from the $3.2 \mathrm{Ga}$ 
Moodies Group, Barberton Greenstone Belt, South Africa. Precambrian Research, 226, 116-124.

6. Chevallier, L., Makanga, J.F., \& Thomas, R.J. (2002). Notice explicative de la Carte géologique de la République gabonaise à 1/1 000 000. Editions DGMG-Ministère des Mines de 1'Energie, du Pétrole et des Ressources Hydrauliques, $195 \mathrm{p}$.

7. Chochine, N. (1950). Notice explicative de la carte géologique de l'A.E.F au 1/500 000. Demi-feuille de la carte du Monde n-A 33-SW Makokou Est. Rapport BRGM-R-0539.

8. Chochine, N. (1951). Rapport sur la reconnaissance géologique de la partie Ouest de la 1/2 feuille n. A.33 S.O.-Makokou (Partie Ouest). Archives DGGRM R-1420.

9. Chochine, N. (1952). Prospection alluvionnaire de la feuille Makokou-Ouest. Archives DGGRM R-3907.

10. Combes, A. (1986c). Fer Haut-Ivindo, Rapport de synthèse. Rapport BRGM-86-GAB-149, 37 p.

11. Combes, A., Derkmann, K., Donzeau, M. Moumpossa, S., Nziba, N., \& Vadala, P. (1986b). Fer Haut-Ivindo, Coupes géologiques et sondages réalisés. Rapport BRGM-86-GAB-094b, $111 \mathrm{p}$.

12. Combes, A., Derkmann, K., Donzeau, M., Moumpossa, S., Nziba, N., \& Vadala, P. (1986a). Fer Haut-Ivindo, Rapport géologique. Rapport BRGM-86-GAB-094a, 178 p.

13. Dalstra, H.J. (2014). Structural evolution of the Mount Wall region in the Hamersley province, Western Australia and its control on hydrothermal alteration and formation of high-grade iron deposits. Journal of Structural Geology, 67, 268-292.

14. Duuring, P., \& Hagemann, S. (2013). Genesis of superimposed hypogene and supergene $\mathrm{Fe}$ orebodies in BIF at the Madoonga deposit, Yilgarn Craton, Western Australia. Mineralium Deposita, 48, 371-395.

15. Fabre, S., Nédélec, A., Poitrasson, F., Strauss, H., Thomazo, C., \& Nogueira, A. (2011). Iron and sulphur isotopes from the Carajás mining province (Pará, Brazil): Implications for the oxidation of the ocean and the atmosphere across the Archean-Proterozoic transition. Chemical Geology, 289, 124-139.

16. Han, C., Xiao, W., Su, B.-X., Sakyi, P.A., Chen, Z., Zhang, X., Ao, S., Zhang, J., Wan, B., Zhang, Z., Wang, Z., \& Ding, J. (2014). Formation age and genesis of the Gongchangling Neoarchean banded iron deposit in eastern Liaoning Province: Constraints from geochemistry and SHRIMP zircon $\mathrm{U}-\mathrm{Pb}$ dating. Precambrian Research, 254, 306-322. 
17. Klein, C. (2005). Some Precambrian banded iron-formations (BIFs) from around the world: Their age, geologic setting, mineralogy, metamorphism, geochemistry, and origin. American Mineralogist, 90, 1473-1499.

18. Martini, J.E.J., \& Makanga, J.-F. (2002). Notice explicative de la carte métallogénique de la République Gabonaise à 1/1 000000. Edition DGMG-Ministère des Mines, de l'Energie, du Pétrole et des Ressources Hydrauliques, 173 p.

19. Pecoits, E., Gingras, M.K., Barley, M.E., Kappler, A., Posth, N.R., \& Konhauser, K.O. (2009). Petrography and geochemistry of the Dales Gorge banded iron formation: Paragenetic sequence, source and implications for palaeo-ocean chemistry. Precambrian Research, 172, 163-187.

20. Plegat, R. (1955b). Mission du fer-Massif Djaddié-Djouah. Etat des travaux après la mission de Juin-Octobre. Archives DGGRM R0357.

21. Prian, J.P., \& Johan, V. (1989). Contribution à la connaissance géologique et pétrographique de l'Archéen du massif du Chaillu et du Francevillien du Bassin des Abeilles (région de Koulamoutou Lastoursville, Gabon central). Rapport BRGM 89 GAB 079 GEO, 66 p.

22. Prian, J.P., Ebang, M., Siméon, Y., Johan, V., Tourlière, B., \& Angel, J.M. (1998). Synthèse géologique et géochimie, potentialités minières du degré carré de Mitzic (Gabon central) avec carte géologique à 1/200 000. Editions DGMG - Ministère des Mines et des Hydrocarbures.

23. Roy, S., \& Venkatesh, A.S. (2009). Mineralogy and geochemistry of banded iron formation and iron ores from eastern India with implications on their genesis. Journal of Earth System Science, 118, 619-641.

24. Schweigart, H. (1965). Genesis of the iron ores of the Pretoria series, South Africa. Economic Geology, 60, 269-298.

25. Sims, S.J. (1973). The Belinga iron ore deposit (Gabon) In: Genesis of Precambrian iron and manganese deposits. Proceedings of the Kiev Symposium, Unesco, 323-334.

26. Spier, C.A., de Oliveira, S.M.B. \& Rosière, C.A. (2003). Geology and geochemistry of the Águas Claras and Pico Iron Mines. Mineralium Deposita, 38, 751-774.

27. Stahl, W., \& Pohner, A. (1957). Gisements des minerais de fer de Mecambo au Gabon-Afrique Equatoriale Française. Rapport BRGM-F-02-224, 70 p. 
28. Telfair, P., \& Hole, G. (1960). The Belinga iron ore deposits, Republic of Gabon. SOMIFER progress report, March, $72 \mathrm{p}$.

29. Thiéblemont, D. (2009c). Carte géologique et des ressources minéralogiques de la République gabonaise. Edition DGMGMinistère des Mines, du Pétrole, des Hydrocarbures.

30. Thiéblemont, D., Bouton, P., Goujou, J.C., Ekogha, H., Boulingui, B., Simo Ndounze, S., Kassadou, A.B., Deschamps, Y., \& Theunissen, K. (2009b). Notice explicative de la Carte géologique de la République du Gabon à 1/200 000, feuille Batouala. Editions DGMG-Ministère des Mines, du Pétrole, des Hydrocarbures, Libreville, $67 \mathrm{p}$.

31. Thiéblemont, D., Castaing, C., Billa, M., Bouton, P., Preat, A. (2009a). Notice explicative de la Carte géologique et des ressources minérales de la République Gabonaise à 1/1 000000 . Editions DGMG-Ministère des Mines, du Pétrole, des Hydrocarbures, Libreville, $384 \mathrm{p}$.

32. Wang, C., Zhang, L., Dai, Y., \& Li, W. (2014a). Source characteristics of the $\sim 2.5 \mathrm{Ga}$ Wangjiazhuang Banded Iron Formation from the Wutai greenstone belt in the North China Craton: Evidence from neodymium isotopes. Journal of Asian Earth Sciences, 93, 288300 .

33. Wang, E.-D., Xia, J.-M., Fu, J.-F., Jia, S.-S., \& Men, Y.-K. (2014). Formation mechanism of Gongchangling high-grade magnetite deposit hosted in Archean BIF, Anshan-Benxi area, Northeastern China. Ore Geology Reviews, 57, 308-321.

34. Webb, A.D., Dickens, G.R., \& Oliver, N.H.S. (2003). From banded iron-formation to iron ore: geochemical and mineralogical constraints from across the Hamersley Province, Western Australia. Chemical Geology, 197, 215-251. 